\title{
ANTI-METALOTOXIC PROPERTIES OF KELAKAI (STENOCHLAENA PALUSTRIS) LEAVES EXTRACT AGAINST CADMIUM-INDUCED LIVER TISSUE DAMAGE
}

\section{AGUNG BIWORO ${ }^{1 *}$, NURUL AINUN AZIZI², RIZKI PADELIA², MUHAMMAD ANDINO RAHARJA ${ }^{2}$, OZANATA AZIMA ${ }^{2}$ EKO SUHARTONO ${ }^{3}$}

${ }^{1}$ Department of Pharmacology, Faculty of Medicine, University of Lambung Mangkurat, Banjarmasin, South Kalimantan, Indonesia. ${ }^{2}$ Faculty of Medicine, University of Lambung Mangkurat, Banjarmasin, South Kalimantan, Indonesia. ${ }^{3}$ Department of Medical Chemistry/ Biochemistry, Faculty of Medicine, University of Lambung Mangkurat, Banjarmasin, South Kalimantan, Indonesia.

Email: ekoantioxidant@gmail.com

Received: 28 August 2018, Revised and Accepted: 29 August 2018

ABSTRACT

Objective: The present study was undertaken to investigate the anti-metalotoxic activity of the leaves extract of Stenochlaena palustris (kelakai; S. palsutris) on cadmium (Cd)-induced liver tissue damage.

Methods: Liver tissue damage was induced by the administration of cadmium sulfate $\left(\mathrm{CdSO}_{4}\right)$ at a dose 3 mg/l. Anti-metalotoxic effect of the extracts was determined by assessing the concentration of malondialdehyde (MDA), carbonyl compound (CC), conjugated dienes (CD), and advanced oxidation protein products (AOPPs) induced by Cd with and without the presence of the extract.

Results: The results of this present studies showed that treatment with $\mathrm{CdSO}_{4}$ significantly increase the levels of MDA, CC, CD, and AOPPs. The leaves extract of $S$. palustris significantly decrease the levels of all measured parameter in liver tissue.

Conclusion: The present study demonstrated that Cd could induced the liver tissue damage, and the extract of $S$. palsutris showed the anti-metalotoxic activity to reduce the damage.

Keywords: Cadmium, Liver, Oxidative Stress, Stenochlaena palustris.

(C) 2018 The Authors. Published by Innovare Academic Sciences Pvt Ltd. This is an open access article under the CC BY license (http://creativecommons. org/licenses/by/4. 0/) DOI: http://dx.doi.org/10.22159/ajpcr.2018.v11s3.30028.

\section{INTRODUCTION}

In South Kalimantan, river is an integral part of human life. Every people in South Kalimantan uses river for various functions of life such as transportation, fishing, and bathing [1]. This causes the people have a great risk to be exposed to various types of pollutants present in river water, such as Cadmium (Cd). Sofarini et al. [2] result study indicated that one of the heavy metals that exceed the maximum threshold in the waters of the Barito River is Cd. The previous study by Rahman [3] showed that the average of $\mathrm{Cd}$ level in the waters of Takisung and Batakan beach was about $0.06 \mathrm{ppm}$ and $0.074 \mathrm{ppm}$, respectively. To the best of our knowledge, Cd levels that are still allowed into the water environment are about $0.00011 \mathrm{ppm}$ and the maximum allowable level is $0.01 \mathrm{ppm}$ [4].

After Cd enters the body, it could be irreversibly accumulates in the human body, in particularly, in kidneys and other vital organs such the lungs or the liver $[5,6]$. These accumulation then might result in some several adverse effects like oxidative stress. Suhartono et al. [7] result study showed that subacute and subchronic Cd exposure could increase the level of malondialdehyde (MDA) and advanced oxidation protein products (AOPPs) in kidney homogenates. Furthermore, our several results study showed that $\mathrm{Cd}$ exposure could induced oxidative stress, lipid peroxidation, and depletes the enzymatic antioxidant activity in brain, liver, and kidney of rats [8-11].

Recently, the study of medicinal plants to prevent and inhibit the oxidative stress-related disease is increasing. Many plants have been known to have such effects, and one of them is Kelakai (Stenochlaena palustris: S. palustris). S. palustris is one of the plants that often grow on wetlands in South Kalimantan. Based on empirical studies, S. palustris has been used daily to treat several medical conditions such as anemia, fever, and skin diseases by the local people of South Kalimantan [12]. Our previous study indicated that $S$. palustris leaves extract could inhibit the formation of methylglyoxal (MG), AOPPs, and carbonyl compound (CC) induced by Cd in vitro. Our another previous study also indicated that S. palustris leaves extract contained flavonoid and has antioxidant activity which is might be useful to inhibit the oxidative stress [13].

However, no data are available in the literature of S. palustris extract on the inhibition of oxidative stress in liver homogenate induced by $\mathrm{Cd}$. Therefore, we undertook the present investigation to examine the anti-metalotoxic effects of S. palustris leaves extract on the Cd-induced liver tissue damage.

\section{METHODS}

\section{Collection and identification of plant materials}

The fresh leaves of $S$. palustris were collected from Gambut subdistrict, South Kalimantan, Indonesia, in April 2017. The plant was authenticated by the Department of Biology of the Pharmacy Study Program, Faculty of Mathematics and Natural Sciences, Lambung Mangkurat University, South Kalimantan, Indonesia. Before use, it was ensured that the leaves and bark were free from contamination, sand, and no microbial growth. The bark and leaves were shade dried and were made into coarse powder using a commercial blender.

\section{Preparation of extracts}

Extraction was done by maceration methods. $50 \mathrm{~g}$ of shade-dried leaves of $S$. plaustris was weighed, and $250 \mathrm{ml}$ of $70 \%$ ethanol-water was added to it, respectively. Then, the mixture was allowed to concentrated in 3 days. The mixture was then filtered 3 times until the filtrate is clear colored. All the filtrate is made into one and then evaporated until thick. Furthermore, the filtrate re-macerated for $24 \mathrm{~h}$ and placed in a test tube in the fridge until it uses for further examination. 


\section{Experimental protocol}

The liver samples were collected from 24 male rats (Rattus norvegicus) with 2-3 month old, weighing 200-250 g. Then, liver samples were taken by surgically procedure with ketamine as anesthesia. Then, the liver fixed in phosphate buffer at $\mathrm{pH}$ 7.0. The liver was ground to form a liquid. Subsequently, the solution was taken and centrifuged at $3500 \mathrm{rpm}$ for $10 \mathrm{~min}$, and the top layer was taken and stored until it uses.

Furthermore, the liver homogenate was prepared to experimental in vitro models. Samples divided into 4 groups ( 1 control group and 3 treatment groups). Control group (C-group): $1 \mathrm{ml}$ of liver homogenate $+1 \mathrm{ml}$ of $3 \mathrm{mg} / \mathrm{l}$ of cadmium sulfate $\left(\mathrm{CdSO}_{4}\right)+1 \mathrm{ml}$ of phosphate buffer with $7.4 \mathrm{pH}$. Treatment 1 group (T1-group): $1 \mathrm{ml}$ of liver homogenate $+1 \mathrm{ml}$ of $3 \mathrm{mg} / \mathrm{l}$ of $\mathrm{CdSO}_{4}+1 \mathrm{ml}$ of phosphate buffer with $7.4 \mathrm{pH}+1 \mathrm{ml}$ of $5 \mathrm{mg} / \mathrm{l}$ of S. palustris leaves extract. Treatment 2 group (T2-group): $1 \mathrm{ml}$ of liver homogenate $+1 \mathrm{ml}$ of $3 \mathrm{mg} / \mathrm{l}$ of $\mathrm{CdSO}_{4}+1 \mathrm{ml}$ of phosphate buffer with $7.4 \mathrm{pH}+1 \mathrm{ml}$ of $10 \mathrm{mg} / \mathrm{l}$ of $S$. palustris leaves extract. Treatment 3 group (T3-group): $1 \mathrm{ml}$ of liver homogenate $+1 \mathrm{ml}$ of $3 \mathrm{mg} / \mathrm{l}$ of $\mathrm{CdSO}_{4}+1 \mathrm{ml}$ of phosphate buffer with $7.4 \mathrm{pH}+1 \mathrm{ml}$ of $15 \mathrm{mg} / \mathrm{l}$ of $S$. palustris leaves extract.

Each solution then incubated at $37^{\circ} \mathrm{C}$ for $1 \mathrm{~h}$. After incubation, liver MDA, CC, conjugated dienes (CD), and AOPPs concentration were estimated. All animals used and care was in compliance of the Ethics Commission of Faculty of Medicine, University of Lambung Mangkurat, Banjarbaru, South Kalimantan, Indonesia.

\section{Liver MDA inhibition assay}

The liver MDA concentration was analyzed according to TBARS method which is previously described by Buege and Aust. $1 \mathrm{ml}$ samples were quickly transferred to assay tubes containing $100 \mu \mathrm{L}$ of $100 \%$ trichloroacetic acid (TCA), $100 \mu \mathrm{L}$ of $1 \%$ Na-Thiobarbiturate, and $250 \mu \mathrm{L}$ of $1 \mathrm{~N}$ hydrochloride acid (HCL). The solution then heated at $100^{\circ} \mathrm{C}$ for 20 min and followed by cooling using ice at room temperature. Then, the solution was centrifuged at $3500 \mathrm{rpm}$ for $10 \mathrm{~min}$, and the supernatant was taken. The absorbance of the supernatant was determined at $532 \mathrm{~nm}$ against a blank solution that contained all reagents, except sample. The MDA concentrations are expressed as $\mu \mathrm{M}$ [14].

\section{Liver CC inhibition assay}

The liver CC concentration was estimated using spectrophotometric 2,4-dinitrophenylhydrazine (DNPH) assay. CC was measured using two tubes, a control and sample tube. The sample tube contained $1 \mathrm{ml}$ sample and $1 \mathrm{ml} \mathrm{DNPH}$, while the control tube contained $1 \mathrm{ml}$ hepatic homogenate control and $2.5 \mathrm{ml} \mathrm{HCl}$. Then, both tubes were incubated for $45 \mathrm{~min}$ at room temperature and protected from sunlight. Both tubes then centrifuged at $1400 \mathrm{rpm}$ for $5 \mathrm{~min}$.

In each tube, $1 \mathrm{ml}$ of $20 \%$ TCA was added and centrifuged again at $1400 \mathrm{rpm}$ for $5 \mathrm{~min}$ to remove the supernatant. $1 \mathrm{ml}$ of $10 \%$ TCA was added to each tube and followed by centrifugation again at $1400 \mathrm{rpm}$ for $5 \mathrm{~min}$ to remove the supernatant. The precipitate then washed 3 times with ethanol/ethyl acetate then dissolved the precipitate in both tubes with $1 \mathrm{ml}$ of $6 \mathrm{M}$ guanidine hydrochloride at $37^{\circ} \mathrm{C}$ for $15 \mathrm{~min}$ with vortex mixing. The absorbance of both tubes was read at $366 \mathrm{~nm}$. The CC level than can be calculated using equation: [15]

CC level $(\mu \mathrm{M})=\frac{\text { Sample Absorbance }- \text { Control Absorbance }}{26}$

\section{Liver CD inhibition assay}

Liver CD concentration was assayed as previously described by Recknagel et al. with minor modifications. Briefly, the sample extracted with chloroform: methanol (2:1) at a ratio of 1:2.5 homogenate to organic solvent mixture. The resulting mixture was centrifuged at $2000 \mathrm{rpm}$ for $8 \mathrm{~min}$. The organic phase containing the CD was taken, dried under nitrogen, solubilized in hexane, and rinsed with $0.003 \mathrm{~N}$ $\mathrm{HCl}$. Samples were analyzed spectrophotometrically at $233 \mathrm{~nm}$, the maximal absorbance for $\mathrm{CD}$, and expressed per nanomole of phosphate.
Total phosphates were quantified by incubating a portion of the dried organic phase for $3 \mathrm{~h}$ with $70 \%$ perchloric acid at $130^{\circ} \mathrm{C}$, followed by the addition of ammonium molybdate and Fiske-Subbarow reagent. Samples or standards were then reheated to $110^{\circ} \mathrm{C}$ for $10 \mathrm{~min}$, cooled, and analyzed spectrophotometrically at $820 \mathrm{~nm}$. Data are expressed as optical density at $233 \mathrm{~nm} / \mathrm{nmol}$ phosphate [16].

\section{Liver AOPPs inhibition assay}

AOPPs measurement was made by spectrophotometric methods as describe by WitkoSarsat et al., with slight modification. Briefly, AOPPs were measured by spectrophotometry on a microplate reader and were calibrated with chloramine-T solutions that in the presence of potassium iodide at $340 \mathrm{~nm}$. In test wells, $200 \mathrm{ml}$ of plasma diluted $1 / 5$ in phosphate buffer solution was placed on a 96-well microtiter plate, and $20 \mathrm{ml}$ of acetic acid was added. In standard wells, $10 \mathrm{ml}$ of $1.16 \mathrm{~mol}$ potassium iodide was added to $200 \mathrm{ml}$ of chloramine-T solution $(0-100 \mathrm{mmol} / \mathrm{l})$ followed by $20 \mathrm{ml}$ of acetic acid. The absorbance of the reaction mixture is immediately read at $340 \mathrm{~nm}$ on the microplate reader against a blank containing $200 \mathrm{ml}$ of phosphate buffer solution, $10 \mathrm{ml}$ of potassium iodide, and $20 \mathrm{ml}$ of acetic acid. The chloramine-T absorbance at $340 \mathrm{~nm}$ being linear within the range of $0-100 \mathrm{mmol} / \mathrm{l}$. AOPP concentrations were expressed as $\mu \mathrm{mol} / \mathrm{l}$ of chloramine-T equivalents [17].

\section{Statistical analysis}

Data were presented as the mean \pm standard error (SE) values. Oneway analysis of variance or Kruskal-Wallis test and followed by a post hoc Tukey's Honestly significant difference or Mann-Whitney test for multiple range test among the group of treatments were performed using a statistical package program (SPSS version 16) for Windows 10. $\mathrm{p}<0.05$ was considered as statistically significant.

\section{RESULTS}

Figure 1a depicts the effect of S. palustris over the actions of MDA. In case of liver damage, the lipid peroxidation levels are meant to get highly elevated, and it was clearly observed in C-group when compared to another group, and in the groups treated with the smallest concentration of $S$. palustris (T1-group), the lipid peroxidation levels were significantly reduced when compared to T1-group. In T2- and T3groups also exhibited increased levels of reduced MDA in comparison with C- and T1-groups.

Figure $1 \mathrm{~b}$ demonstrates that $\mathrm{Cd}$ exposure (C-group) is significantly increased the level of liver CC. These figure further demonstrates that S. palustris extract is significantly decrease the level of liver CC, in a concentration-dependent manner.

Figure $2 \mathrm{a}$ represented the mean values $\pm(M e a n \pm S E)$ of liver $C D$ concentration. All groups of treatment (T1-, T2-, and T3-groups) show a lower CD concentration compare to C-group. Statistical analysis test results show treatment with $S$. palustris extract led to a significant decrease of their levels in comparison with the C-group.

Figure $2 \mathrm{~b}$ represented the mean values $\pm($ Mean \pm SE) of liver AOPPs concentration. All groups of treatment (T1-, T2-, and T3-groups) show a lower AOPPs concentration compare to C-group. Statistical analysis test results show treatment with $S$. palustris extract led to a significant decrease of their levels in comparison with the C-group.

\section{DISCUSSION}

The present study reflects the anti-metalotoxic activity of $S$. palustris extract against $\mathrm{Cd}$-induced oxidative stress in liver tissue of rats. In our experiments, $\mathrm{Cd}$ exposure had increased peroxidation of membrane lipids of liver tissue. It was indicated by the increasing of liver MDA and CD concentration. Lipid peroxidation is primarily an outcome of oxidative stress by reactive oxygen species (ROS) [18]. The mechanism of induction of lipid peroxidation by $\mathrm{Cd}$ is still poorly understood. In general, $\mathrm{Cd}$ is unable to directly cause the formation of ROS under 


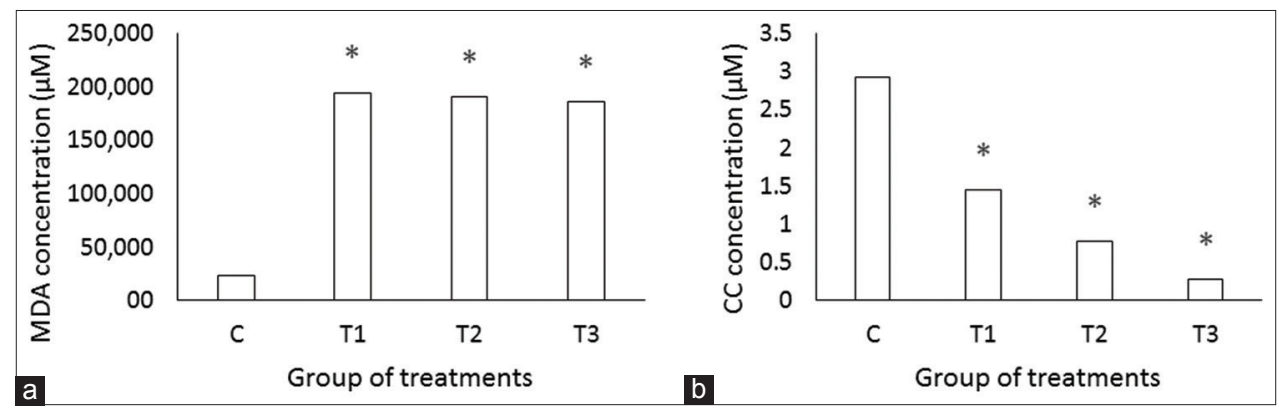

Fig. 1: Effect of Stenochlaena palustris on liver (a) malondyaldehyde and (b) carbonyl compound concentration over cadmium sulfate administration. Values are mean \pm standard error of the mean of four replicates in each groups of treatment. Statistical significance ${ }^{*} \mathbf{p}<0.05$ in comparison with control group

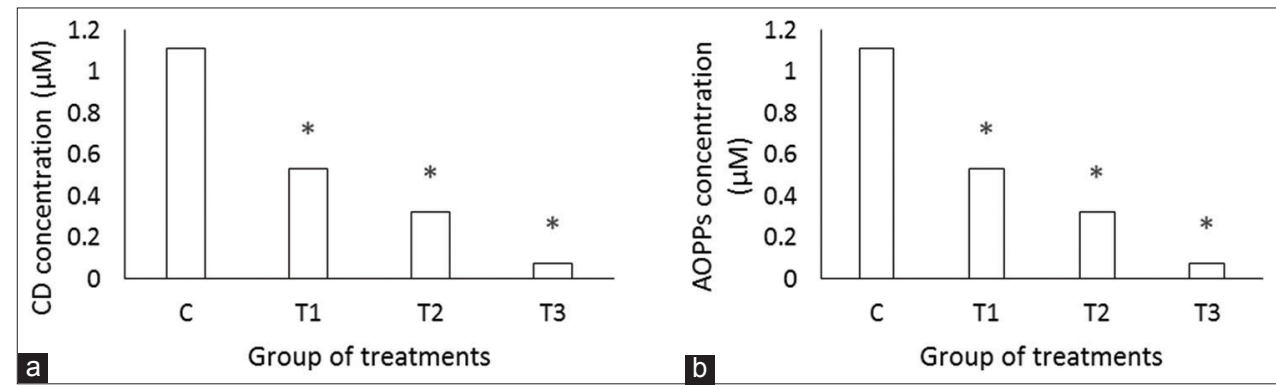

Fig. 2: Effect of Stenochlaena palustris on liver (a) conjugated dienes and (b) advanced oxidation protein products concentration over cadmium sulfate administration. Values are mean \pm standard error of the mean of four replicates in each group of treatment. Statistical significance $* \mathbf{p}<0.05$ in comparison with the control group

physiological conditions [19]. Several previous authors suggested that Cd could induced the formation of ROS through severar pathway: (1) Replacing Fe in Fenton reaction; (2) affect the enzymatic antioxidant; (3) impaired glutathione which is known as ROS scavenger; and (4) inhibited complex II and III in electron transport chain reaction [20]. Those four pathways will trigger the formation of ROS which will promote a further reaction resulted in lipid peroxidation that is characterized by the formation of MDA and CD [21,22].

Besides lipid, protein also a main target for oxidative stress condition. ROS could directly oxidized protein to form several protein carbonyl compound. This in line with the result of this present study that $\mathrm{Cd}$ exposure which is increase the formation of ROS result in increase the level of liver CC. ROS could oxidize arginine and proline to produce glutamic semialdehyde, and lysine to produce aminoadipic semialdehyde. Both protein oxidation products by ROS known as CC which is the most widely used biomarker for oxidative damage [23].

Recently, another biomarker for protein damage in oxidative stress condition was proposed, known as AOPPs. It was first described in 1996 by Witko-sarsat et al. who found this new biomarker in chronic uremic patients [24]. AOPPs are described as dityrosine containing cross-linked protein products which are result from the direct reaction between ROS and protein [25]. The result of our present experiments indicated that $\mathrm{Cd}$ increases the formation of AOPPs. The main reason might why Cd could increase AOPPs might because the ability of $\mathrm{Cd}$ generate ROS as mentioned before.

The result of this present study also indicated that the S. palustris extract is found to be effective in decreasing the lipid and protein damage by $\mathrm{Cd}$ in liver tissue. The result of this study is also accordance with our previous experiments which reported decrease MG, MDA, and AOPPs by $S$. palustris extract in glycation and fructation reaction model with $\mathrm{Cd}$ as a catalyst [26].

The inhibition effect of $S$. palustris extract might because of the phytochemical constituents such as flavonoid, phenolic compound, and alkaloid. Those all phytochemical constituents were responsible for inhibiting the Cd toxicity. All phytochemical constituents in S. palustris extractable to bind particularly to metals, including Cd. Thus, the extract will slow down the rate formation of all measured parameters [13].

\section{CONCLUSION}

It can be concluded from the presented results that Cd-induced oxidative damage in liver tissues by enhanced lipid peroxidation as well as protein damage. Moreover, the extract of $S$. palustris expressed anti-metalotoxic activity against $\mathrm{Cd}$. S. palustris extract may exert its anti-metalotoxic actions against $\mathrm{Cd}$-induced oxidative stress in liver tissues possibly through its chelating metal mechanism. The results raise the possibility of $S$. palustris extract being considered as one of the promising medicinal plants of the people in the areas, where they may have chances of exposure to $\mathrm{Cd}$ occupationally or environmentally. Further studies are undergoing to clarify their molecular mechanisms.

\section{ACKNOWLEDGMENT}

The authors are grateful to the financial support by Faculty of Medicine, Lambung Mangkurat University, Banjarmasin, South Kalimantan, Indonesia.

\section{CONFLICTS OF INTEREST}

We declare that we have no conflicts of interest.

\section{REFERENCES}

1. Normelani E. River, culture and tourism in Lok Baintan, South Kalimantan. J Ind Tour Dev Std 2016;4:57-62.

2. Sofarini D, Rahman A, Ridwan I. Study of cadmium test analysis on water bodies, biota, and sediments in the waters of the Barito River watershed. Bumi Lestari J Environ 2010;1:28-37.

3. Rahman $\mathrm{A}$. The content of lead $(\mathrm{Pb})$ and cadmium $(\mathrm{Cd})$ in some types of crustaceans in Batakan Beach and Takisung Regency Tanah Laut, South Kalimantan. Bioscientiae 2006;3:93-101.

4. Komari N, Irawati U, Novita E. The content of cadmium and zinc in 
baung fish (Hemibagrus nemurus) in Trisakti Waters Banjarmasin, South Kalimantan. Sci Appl Chem 2013;7:42-9.

5. Bernard A. Cadmium and its adverse effects on human health. Indian J Med Res 2008:128:557-64.

6. Markiewicz-Górka I, Januszewska L, Michalak A, Prokopowicz A, Januszewska E, Pawlas N, et al. Effects of chronic exposure to lead, cadmium, and manganese mixtures on oxidative stress in rat liver and heart. Arh Hig Rada Toksikol 2015;66:51-62.

7. Suhartono E, Triawanti, Leksono AS, Djati MS. Effects of cadmium exposure on lipid peroxidation and chlorinative stress of rat kidney. J Exp Life Sci 2015;5:1-5

8. Suhartono E, Triawanti, Yunanto A, Firdaus RT, Iskandar TF. Chronic cadmium hepatooxidative in rats: Treatment with haruan fish (Channa striata) extract. APCBEE Proc 2013;5:441-5.

9. Aflanie I, Muhyi R, Suhartono E. Effect of heavy metal on malondialdehyde and advanced oxidation protein produtcs concentration: A focus on arsenic, cadmium, and mercury. J Med Biol Eng 2015;4:332-7.

10. Suhartono E, Iskandar, Hamidah S, Arifin YF. Phytochemical constituents analysis and neuroprotective effect of leaves of gemor (Nothaphoebe Coriacea) on cadmium-induced neurotoxicity in rats: An in-vitro study. Int J Toxicol Pharm Res 2015;7:297-302.

11. Suhartono E, Nijka JA, Anhar VY, Sari RA, Edyson E, Marisa D. Anti-lipid peroxidation activities of three selected fruits juices against cadmium induced liver damage in vitro. J Trop Life Sci 2015;5:75-9.

12. Karantika EA, Edyson S, Suhartono E. Kinetic parameters analysis of liver and kidney catalase under the influence of cadmium (Cd) and mercury (Hg) in vitro. J Trop Life Sci 2016;6:65-8.

13. Suhartono E, Bahriansyah M, Triawanti T. The inhibition effect of kelakai (Stenochlaena palustris) extract on cadmium-induced glycation and fructation in-vitro. Int J Pharm Clin Res 2016;8:248-53.

14. Suhartono E, Viani E, Rahmadhan MA, Gultom IS, Rakhman MF, Indrawardhana D. Screening of medicinal plant for total flavonoid and antioxidant activity in South Kalimantan of Indonesian. Int J Chem Eng Apl 2012;3:297-9.

15. Aflanie I, Sari NN, Suhartono E. Oxidative and chlorinative stress biomarkers in liver cells of rats exposed to cyanide in-vitro. Int J Pharm
Clin Res 2016;8:1441-5.

16. Suhartono E, Triawanti, Leksono AS, Djati MS. The role of cadmium in protein glycation by glucose: Formation of methylglyoxal and hydrogen peroxide in vitro. J Med Biol Eng 2014;3:59-62.

17. Hoglen NC, Younis HS, Hartley DP, Gunawardhana L, Lantz RC, Sipe IE. 1,2-dichlorobenzene-Induced lipid peroxidation in male fischer 344 rats is kupffer cell dependent. Toxicol Sci 1998;46:376-85.

18. Yunanto A, Iskandar S, Suhartono E. In-vitro effects of some antibiotic drugs on saliva thiocyanate and oxidation protein products levels on newborn at risk of sepsis. Int J Pharm Clin Res 2016;8:86-9.

19. Mitra E, Ghosh D, Ghosh AK, Basu A, Chattopadhay A, Pattari SK, et al. Aqueous tulsi Leaf (Ocimum sanctum) extract posseesses antioxidant properties adn protec against cadmium-induced oxidative stress in rat heart. Int J Pharm Pharm Sci 2013;6:500-13.

20. Haouem S, El Hani A. Effect of cadmium on lipid peroxidation and on some antioxidants in the liver, kidneys and testes of rats given diet containing cadmium-polluted radish bulbs. J Toxicol Pathol 2013;26:359-64.

21. Nair AR, Degheselle O, Smeets K, Van Kerkhove E, Cuypers A. Cadmium-induced pathologies: Where is the oxidative balance lost (or not)? Int J Mol Sci 2013;14:6116-43.

22. Anjum NA, Sofo A, Scopa A, Roychoudhury A, Gill SS, Iqbal M, et al. Lipids and proteins-major targets of oxidative modifications in abiotic stressed plants. Environ Sci Pollut Res Int 2015;22:4099-121.

23. Ayala A, Muñoz MF, Argüelles S. Lipid peroxidation: Production, metabolism, and signaling mechanisms of malondialdehyde and 4-hydroxy-2-nonenal. Oxid Med Cell Longev 2014;2014:360438.

24. Witko-Sarsat V, Friedlander M, Capeillere-Blandin C, NguyenKhoa T, Nguyen AT, Zingraff J, et al. Advanced oxidation protein products as a novel marker of oxidative stress in uremia. Kidney Int 1996:49:1304-13

25. Başkol M, Dolbun Seçkin K, Başkol G. Advanced oxidation protein products, total thiol levels and total oxidant/antioxidant status in patients with nash. Turk J Gastroenterol 2014;25 Suppl 1:32-7.

26. Zuwała-Jagiełło J, Pazgan-Simon M, Simon K, Warwas M. Elevated advanced oxidation protein products levels in patients with liver cirrhosis. Acta Biochim Pol 2009;56:679-85. 